\title{
Coral-associated viruses and bacteria in the Ha Long Bay, Vietnam
}

\author{
The Thu Pham ${ }^{1}$, Van Thuoc Chu ${ }^{1}$, Thi Viet Ha Bui ${ }^{2}$, Thanh Thuy Nguyen ${ }^{3}$, \\ Quang Huy Tran ${ }^{3}$, Thi Ngoc Mai Cung ${ }^{4}$, Corinne Bouvier ${ }^{5}$, Justine Brune ${ }^{5}$, Sebastien \\ Villeger $^{5}$, Thierry Bouvier ${ }^{5}$, Yvan Bettarel ${ }^{5, *}$
}

\author{
${ }^{1}$ Institute of Marine Environment and Resources (IMER), Vietnam Academy of Science and Technology (VAST), Haiphong, Vietnam \\ ${ }^{2}$ Hanoi University of Science, Vietnam National University (VNU), Hanoi, Vietnam \\ ${ }^{3}$ National Institute of Hygiene and Epidemiology (NIHE), Hanoi, Vietnam \\ ${ }^{4}$ Institute of Biotechnology (IBT), VAST, Hanoi, Vietnam \\ ${ }^{5}$ UMR MARBEC, Institut de Recherche pour le Développement (IRD), CNRS, Université Montpellier, France
}

\begin{abstract}
Viruses inhabiting the surface mucus layer of scleractinian corals have received little ecological attention so far. Yet they have recently been shown to be highly abundant and could even play a pivotal role in coral health. A fundamental aspect that remains unresolved is whether their abundance and diversity change with the trophic state of their environment. The present study examined the variability in the abundance of viral and bacterial epibionts on 13 coral species collected from 2 different sites in the Ha Long Bay, Vietnam: one station heavily affected by anthropogenic activity (Cat Ba Island) and one protected offshore station (Long Chau Island). In general, viral abundance was significantly higher in coral mucus (mean $=10.6 \pm 2.0 \times 10^{7}$ viruslike particles ml$\left.{ }^{-1}\right)$ than in the surrounding water $\left(5.2 \pm 1.3 \times 10^{7}\right.$ virus-like particles $\left.\mathrm{ml}^{-1}\right)$. Concomitantly, the abundance and community diversity (inferred from phylogenetic and morphological analyses) of their mucosal bacterial hosts strongly differed from their planktonic counterparts. Surprisingly, despite large differences in water quality and nutrient concentrations between Cat Ba and Long Chau, there were no significant differences in the concentrations of epibiotic viruses and bacteria measured in the only 2 coral species (i.e. Pavona decussata and Lobophyllia flabelliformis) that were common at both sites. The ability of corals to shed bacteria to compensate for their fast growth in nutrient-rich mucus is questioned here.
\end{abstract}

KEY WORDS: Viruses $\cdot$ Coral-associated bacteria $\cdot$ Mucus $\cdot$ Symbionts $\cdot$ Coral reefs

\section{INTRODUCTION}

Coral reefs are among the most fragile marine habitats (Pandolfi et al. 2011), and they have experienced a rapid and strong decline over the past 3 decades (Hughes et al. 2003, Pandolfi et al. 2003, Bourne et al. 2009). Beside the destructive effects of hurricanes and predation (e.g. by corallivorous fish, snails and starfish) (Cole et al. 2011, Kayal et al. 2012, Hoeksema et al. 2013), microbial diseases are among the major causes for such decline of coral reefs worldwide (Rosenberg et al. 2009, Pollock et al. 2014). Their occurrence and intensity have consider- ably increased in recent years, probably favored by climate change and the expanding anthropization and subsequent contamination of coastal waters (Harvell et al. 2002, Lesser et al. 2007). Efforts have been made to better identify the agents responsible for these coral diseases, and knowledge on the underlying ecological and physiological processes has greatly improved in the past few years. For example, we now have a much clearer vision of the role of prokaryotes in the development, progress and collapse of coral diseases such as the black-band disease (Bourne et al. 2011), white-band disease (Lentz et al. 2011), white plague (Cárdenas et al. 2012) and 
white pox (Alagely et al. 2011). Several diseases have been shown to be caused by pathogens, such as members of the Vibrionaceae family (Kushmaro et al. 2001, Ben-Haim et al. 2003, Gomez-Gil et al. 2004, Cervino et al. 2008, Arotsker et al. 2009). Paradoxically, prokaryotes are also recognized for their symbiotic and species-specific association with corals (Rohwer et al. 2002, Goulet 2006, Apprill et al. 2012). For example, their ability to protect against invasive pathogens by the production of antibiotic compounds has long been described (Ritchie \& Smith 2004, Reshef et al. 2006, Rypien et al. 2010, Shnit-Orland et al. 2012).

In the water column, prokaryotes are strongly subjected to lytic viral pressure, which usually accounts for 10 to $50 \%$ of bacterial mortality (Jardillier et al. 2005, Suttle 2007). There is increasing interest from marine microbiologists to study viruses inhabiting the superficial microlayer of corals, where they have been found to be highly abundant (Davy \& Patten 2007, Leruste et al. 2012, Nguyen-Kim et al. 2014, 2015) and genetically diverse (Marhaver et al. 2008, Vega Thurber et al. 2009). Preliminary investigations on viral morphotypes and viral metagenomes in coral mucus have revealed that viruses can potentially infect all the prokaryotic and eukaryotic components of the holobiont (Marhaver et al. 2008). Not surprisingly then, viruses infecting bacteria and the symbiotic dinoflagellates Symbiodinium spp. are now considered integrative members of the viral assemblage (Wilson et al. 2005, Lohr et al. 2007, Vega Thurber et al. 2009, Correa et al. 2013). Many microbiologists even suspect that they could play a decisive role for coral viability by a strategic and environmentally driven control on both pathogenic and symbiotic microorganisms (Van Oppen et al. 2009, Vega Thurber \& Correa 2011, Bettarel et al. 2014). Indeed, if viruses could represent a lytic barrier against colonization of surrounding pathogens (Barr et al. 2013a), they could also, via lysogenic infection, paradoxically protect bacterial symbionts from other viruses through lytic and lysogenic infection (Bettarel et al. 2014, NguyenKim et al. 2015). However, still little is known about the factors that govern the distribution of such epibiotic viruses. For example, we lack information on whether global warming, nutrient enrichment of coastal waters, terrigenous sediment run-off, or anthropogenic environmental pollutants can alter viral community structure and therefore may influence their ecological role within the coral holobiont (Vega Thurber et al. 2008). Such information is crucial to elucidate the effective contributions of viruses to coral health.
To address this gap, our general objective was to examine the ecological traits of planktonic and epibiotic viruses and bacteria from 14 scleractinian coral species at 2 sites of different trophic status in the Ha Long Bay (Vietnam). Specifically, we first investigated the potential links between viral distribution and the abundance and morphological and phylogenetic diversity of their bacterial hosts. The second objective was to explore whether these viral and bacterial traits were influenced by the water quality and nutritive environment.

\section{MATERIALS AND METHODS}

\section{Description of study sites and sampling strategy}

The water and coral mucus samples were collected on 29 and 30 May 2012, between 07:00 h and 15:00 h during neap tide, in the vicinity of the United Nations Educational, Scientific and Cultural Organization World Heritage Site of Ha Long Bay (northern Vietnam) (Fig. 1). Two contrasting stations were sampled (see Faxneld et al. 2011). One is located in the Cat Ba archipelago (204 $\left.7^{\prime} 19.31^{\prime \prime} \mathrm{N}, 107^{\circ} 5^{\prime} 42.87^{\prime \prime} \mathrm{E}\right)$ and is subject to intense touristic and aquacultural activities and high industrial sediment loads. This disturbed (i.e. nearshore) reef area is situated close to the coast, in a semi-enclosed area with limited water exchange, and receives run-off water from several rivers. The other station, at Long Chau Island $\left(20^{\circ} 37^{\prime} 57.45^{\prime \prime} \mathrm{N}, 107^{\circ} 8^{\prime} 46.41^{\prime \prime} \mathrm{E}\right)$, is not affected by anthropogenic activities, given its nature as a de facto marine protected area due to its military status (Thanh et al. 2004). This offshore area is located approximately $30 \mathrm{~km}$ south of the nearshore reef area and is an open zone with good water exchange; it is less affected by land run-off water (Faxneld et al. 2011)

The mucus from a total of 13 coral species was sampled according to the recommendation from Leruste et al. (2012) at Cat Ba Island (Pavona spp., Pavona decussata, Fungia fungites, Sandolitha robusta, Goniastrea pectinata, Lobophyllia flabelliformis, Lobophyllia hemprichii) and Long Chau Island (Pavona frondifera, P. decussata, L. flabelliformis, Acropora hyacinthus, Acropora pulchra, Echinopora lamellosa, Favites pentagona and Platygyra carnosus). Thus, 2 coral species (i.e. P. decussata and L. flabelliformis) were common to both sites. Briefly, duplicate biological samples of each coral species were collected by SCUBA diving from depths of 3 to $10 \mathrm{~m}$. Mucus was collected using the desiccation method described in 
detail elsewhere (Wild et al. 2005, Naumann et al. 2009). All coral samples were taken out of the water and exposed to air for 1 to $3 \mathrm{~min}$, depending on the time for mucus secretion, which was variable among coral species. This stress caused the mucus to be secreted, forming long gel-like threads dripping from the coral surface. As recommended by Wild et al. (2005), the first $20 \mathrm{~s}$ of mucus production was discarded to prevent contamination and dilution by seawater. The fresh mucus ( 3 to $6 \mathrm{ml}$ ) was then distributed in polycarbonate tubes and immediately processed for DNA extraction and DGGE analyses, cell respiring activity and metabolic capacities, as well as concentration of culturable bacteria. One milliliter of mucus was transferred into $2 \mathrm{ml}$ cryotubes, immediately fixed with formaldehyde (final concentration $3 \% \mathrm{v} / \mathrm{v}$ ), flash-frozen in liquid nitrogen and stored at $-80^{\circ} \mathrm{C}$ until staining for viral and bacterial abundance analyses. Fifty milliliter duplicate seawater samples were also collected at approximately $1 \mathrm{~m}$ above the coral species, fixed and stored for the various analyses, as described for mucus samples.

\section{Physicochemical parameters}

Duplicate seawater samples were analyzed for nutrient and chl a contents, as well as for the different bacterial and viral parameters. Samples for nutrient measurements $\left(\mathrm{N}-\mathrm{NO}_{2}, \mathrm{~N}-\mathrm{NO}_{3}, \mathrm{~N}-\mathrm{NH}_{4}, \mathrm{P}-\mathrm{PO}_{4}\right)$ were filtered through precombusted Whatman GF/F fiberglass filters, stored at $-20^{\circ} \mathrm{C}$ and analyzed according to Eaton et al. (1995). Chl a concentrations were determined by fluorometry (excitation wave length: $470 \mathrm{~nm}$ ) after filtration onto Whatman GF/F filters and methanol extraction (Holm-Hansen et al. 1965). The chemical oxygen demand (COD) was estimated using potassium permanganate as oxidizing agent (Hossain et al. 2013). Salinity and temperature were measured in situ, $1 \mathrm{~m}$ above the corals species, using a CTD probe (SBE 19+, Sea-Bird Electronics).

\section{Bacterial and viral concentrations}

At each site and for each coral species, duplicate subsamples of $100 \mu \mathrm{l}$ of fixed mucus were eluted into $900 \mu \mathrm{l}$ of a solution of $0.02 \mu \mathrm{m}$ pore-size-filtered, $\mathrm{pH}$ 7 solution of $1 \%$ citrate potassium (made with $10 \mathrm{~g}$ potassium citrate, $1.44 \mathrm{~g} \mathrm{l}^{-1} \mathrm{Na}_{2} \mathrm{HPO}_{4} \cdot 7 \mathrm{H}_{2} \mathrm{O}$ and $0.24 \mathrm{~g} \mathrm{l}^{-1} \mathrm{KH}_{2} \mathrm{PO}_{4}$ ) (Nguyen-Kim et al. 2014, adapted from Williamson et al. 2003). Samples were then vortexed at moderate speed for $5 \mathrm{~min}$, and the number of viruses and bacteria contained in 200 to $500 \mu \mathrm{l}$ of mucus solution was estimated after retention of the particles onto $0.02 \mu \mathrm{m}$ pore size membranes (Whatman Anodisc), rinsing with $500 \mu \mathrm{l}$ TE buffer and staining with the nucleic acid dye, SYBR Gold (Invitrogen) for $15 \mathrm{~min}$. The different microorganisms were then counted using an epifluorescence microscope (Olympus BX51), under blue light (excitation wave length: $450 \mathrm{~nm}$ ), as described in detail by Patel et al. (2007). The whole procedure is detailed in Leruste et al. (2012). The average proportion of the main bacterial morphotypes (rods, cocci, curved cells and filaments) was also evaluated for each sample. For the planktonic free-living viruses and bacteria, the above standard staining procedure was applied to $500 \mu \mathrm{l}$ of seawater, but without the potassium citrate extraction step, which was unnecessary.

\section{Enumeration of culturable heterotrophic bacteria and vibrio species}

Culturable heterotrophic bacteria (C-BAC) and culturable Vibrionaceae (C-VIB) were counted (one replicate) by plating $50 \mu \mathrm{l}$ of serial dilutions (1 and $100 \%$ ) of both mucus and seawater samples, respectively, on (1) the non-selective artificial seawater (ASW) medium (Smith \& Hayasaka 1982) and (2) the vibrio-selective medium thiosulphate citrate bile saltssucrose agar (TCBS) (Uchiyama 2000). After $48 \mathrm{~h}$ incubation at in situ temperature, colony-forming units were counted in all the different plates. Counts did not increase after prolonged incubation.

\section{DGGE bacterial community composition}

The community structure of mucosal and planktonic bacteria was determined by denaturing gradient gel electrophoresis (DGGE) analysis of 16S rRNA gene fragments (Morrow et al. 2012). Briefly, $50 \mathrm{ml}$ of seawater and $2 \mathrm{ml}$ of coral mucus of each species were filtered onto $0.2 \mu \mathrm{m}$ polycarbonate filters (Whatman) for total DNA extraction and stored at $-20^{\circ} \mathrm{C}$ until analysis. The PowerSoil DNA Isolation Kit was used to extract DNA from both water and mucus samples. The DNA sequences were then subjected to touchdown PCR using the primers 341F-GC and 518R (Ovreås et al. 1997), which target bacterial 16S rRNA genes (178 bp). PCR was carried out using $10 \mathrm{ng}$ of extracted DNA and PuRe Taq Ready-To-Go PCR beads (GE Healthcare) using the PCR touchdown program (Muyzer et al. 1993). PCR products 
were verified in $1.5 \%(\mathrm{wt} / \mathrm{vol})$ agarose gel using SYBR Gold I nucleic acid gel stain (1:10 000 dilution; Molecular Probes). PCR samples were loaded onto $8 \%(\mathrm{wt} / \mathrm{vol})$ polyacrylamide gels made with a denaturing gradient ranging from 35 to $65 \% \quad(100 \%$ denaturant contains $7 \mathrm{M}$ urea and $40 \%$ formamide). The DGGE was performed with an Ingeny Phor-U system in $0.5 \times$ tris-acetate-EDTA (TAE) buffer (Euromedex) at $60^{\circ} \mathrm{C}$ with a constant voltage of $80 \mathrm{~V}$ for $18 \mathrm{~h}$. The DNA was then stained with the SYBR Gold nucleic acid dye. DNA bands were visualized on a UV trans-illumination table with the imaging system GelDoc XR (Bio-Rad) and analyzed using fingerprint and gel analysis Quantity One software (Bio-Rad). Band matching was performed with $1.00 \%$ position tolerance and $1.00 \%$ optimization. A band-matching table was generated to obtain the binary presence/absence matrix. Each DGGE band refers to operational taxonomic units (OTUs) representative of predominant bacterial taxa (Reche et al. 2005). The total number of OTUs was used to compare the richness between prokaryotic communities of all the samples. Similarity between DGGE profiles was obtained with an agglomerative hierarchical clustering analysis, which is based on the relative intensity matrix.

\section{Data analysis}

Data were $\log$ transformed to satisfy requirements of normality and homogeneity of variance necessary for parametric analyses. A 1-way ANOVA was used to compare the different bacterial and viral parameters between habitats (mucus and seawater) and geographical sampling sites (Cat Ba and Long Chau) for the 2 common species ( $P$. decussata and $L$. flabelliformis). The variability of bacterial community compositions between all samples and between the 2 common species (site effect) was assessed using a non-parametric statistical test. Briefly, we first computed the Jaccard dissimilarity index of the DGGE profiles (based on the presence/absence of OTUs) both between all pairs of corals and between the 2 common species. Variance of dissimilarity was computed according to Anderson (2001, 2006) (R functions permutest and betadisper from the library vegan, permutational MANOVA [PERMANOVA]) and based on permutations of actual dissimilarity values. Simple relationships between original data sets were also tested using Pearson correlation analysis. All statistical analyses were performed using XLSTAT software.

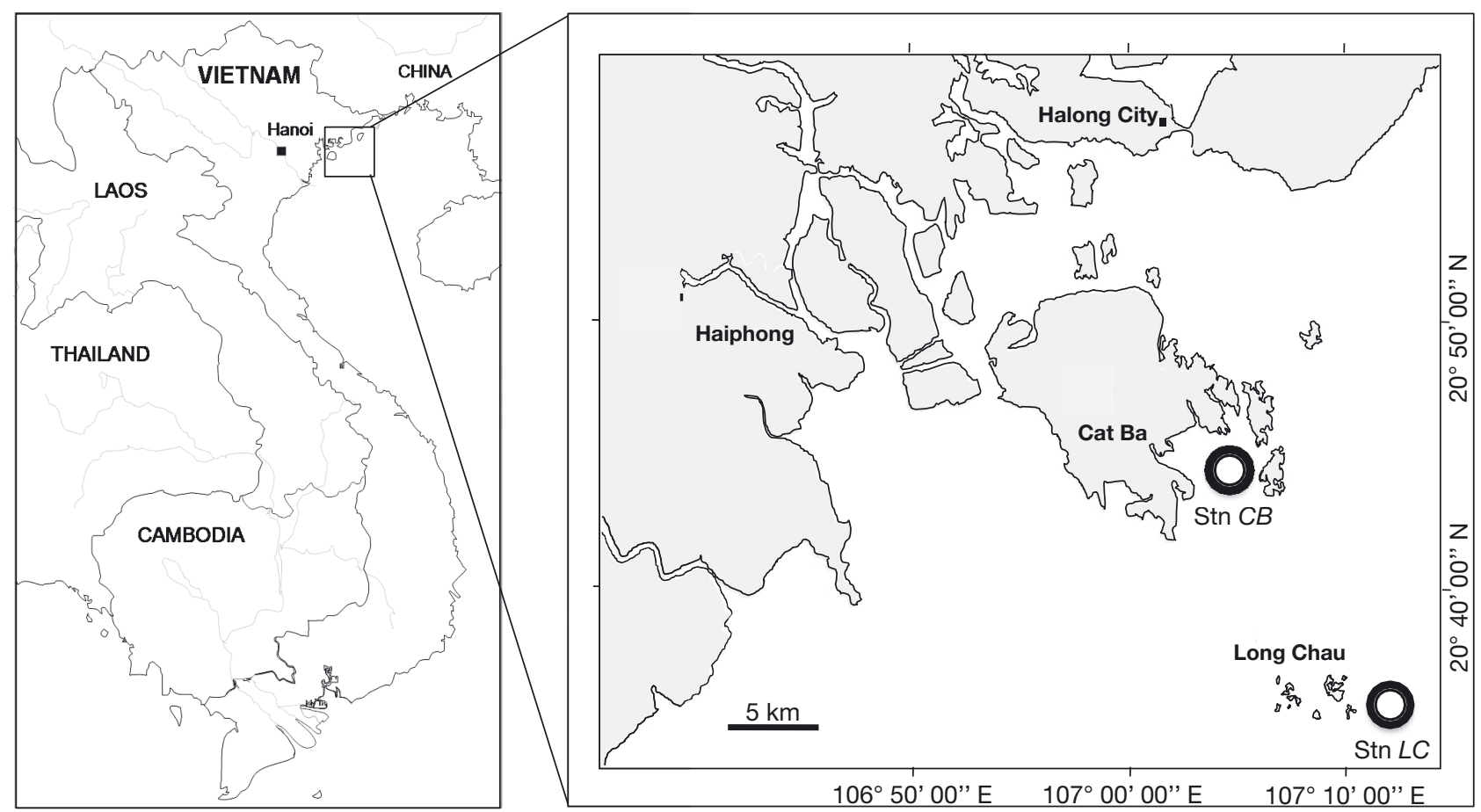

Fig. 1. Location of the 2 sampling sites, Cat Ba and Long Chau Island stations, in Ha Long Bay, northern Vietnam, Southeast Asia. CB: Cat Ba; LC: Long Chau 


\section{RESULTS}

\section{Environmental variables}

During the sampling period, the 2 sites were highly contrasted in their physicochemical characteristics. Cat $\mathrm{Ba}$, the site most heavily affected by anthropogenic activities, exhibited a higher nutrient concentration, water turbidity and COD, compared with the remote Long Chau Island (Table 1). For example, chl a, nitrite, nitrate, ammonium and phosphate concentrations were 71, 114, 147, 28 and $49 \%$ higher, respectively, in Cat Ba than in Long Chau (Table 1). During the sampling, no trace of coral bleaching or injuries was observed in any of the sampled coral species.

\section{Viral and bacterial abundances}

Viral abundance was consistently and significantly higher in coral mucus than in the surrounding seawater, being 1.4 and $2.8 \times$ higher, respectively, in Cat Ba and Long Chau. With the exception of Goniastrea pectinata in Cat Ba and Acropora hyacinthus in Long Chau, values generally comprised between $10 \times 10^{7}$ and $14 \times 10^{7}$ viruses $\mathrm{ml}^{-1}$ mucus (Fig. 2). In the 2 coral

Table 1. Geographical coordinates and physicochemical parameters of seawater in the 2 sampling stations. FTU: formazin turbidity unit; COD: chemical oxygen demand

\begin{tabular}{|c|c|c|c|c|c|c|c|c|c|c|}
\hline Site & $\begin{array}{l}\text { Latitude, } \\
\text { Longitude }\end{array}$ & $\begin{array}{l}\text { Temp. } \\
\left({ }^{\circ} \mathrm{C}\right)\end{array}$ & $\begin{array}{l}\text { Salinity } \\
(\% \circ)\end{array}$ & $\begin{array}{c}\mathrm{Chl} \mathrm{a} \\
\left(\mathrm{mg} \mathrm{l}^{-1}\right)\end{array}$ & $\begin{array}{l}\text { Turbidity } \\
\text { (FTU) }\end{array}$ & $\begin{array}{c}\mathrm{COD} \\
\left(\mathrm{mg} \mathrm{l}^{-1}\right)\end{array}$ & $\begin{array}{l}\mathrm{N}-\mathrm{NO}_{2} \\
\left(\mu \mathrm{g} \mathrm{l}^{-1}\right)\end{array}$ & $\begin{array}{l}\mathrm{N}-\mathrm{NO}_{3} \\
\left(\mu \mathrm{g} \mathrm{l}^{-1}\right)\end{array}$ & $\begin{array}{l}\mathrm{N}-\mathrm{NH}_{4} \\
\left(\mu \mathrm{g} \mathrm{l}^{-1}\right)\end{array}$ & $\begin{array}{l}\mathrm{P}-\mathrm{PO}_{4} \\
\left(\mu \mathrm{g} \mathrm{l}^{-1}\right)\end{array}$ \\
\hline Cat Ba & $\begin{array}{l}20^{\circ} 47^{\prime} 19.31^{\prime \prime} \mathrm{N} \\
107^{\circ} 5^{\prime} 42.87^{\prime \prime} \mathrm{E}\end{array}$ & $30.1 \pm 0.1$ & 29.1 & $1.2 \pm 0.2$ & $1.5 \pm 0.3$ & $2.5 \pm 0.1$ & $7.9 \pm 0.8$ & $166.7 \pm 14.5$ & $39.3 \pm 1.7$ & $20.2 \pm 0.9$ \\
\hline $\begin{array}{l}\text { Long } \\
\text { Chau }\end{array}$ & $\begin{array}{c}20^{\circ} 37^{\prime} 57.45^{\prime \prime} \mathrm{N} \\
107^{\circ} 8^{\prime} 46.41^{\prime \prime} \mathrm{E}\end{array}$ & $29.0 \pm 0.2$ & 31.5 & $0.7 \pm 0.1$ & $0.7 \pm 0.1$ & $1.9 \pm 0.2$ & $3.7 \pm 1.0$ & $67.5 \pm 9.3$ & $30.7 \pm 0.8$ & $13.6 \pm 2.2$ \\
\hline
\end{tabular}
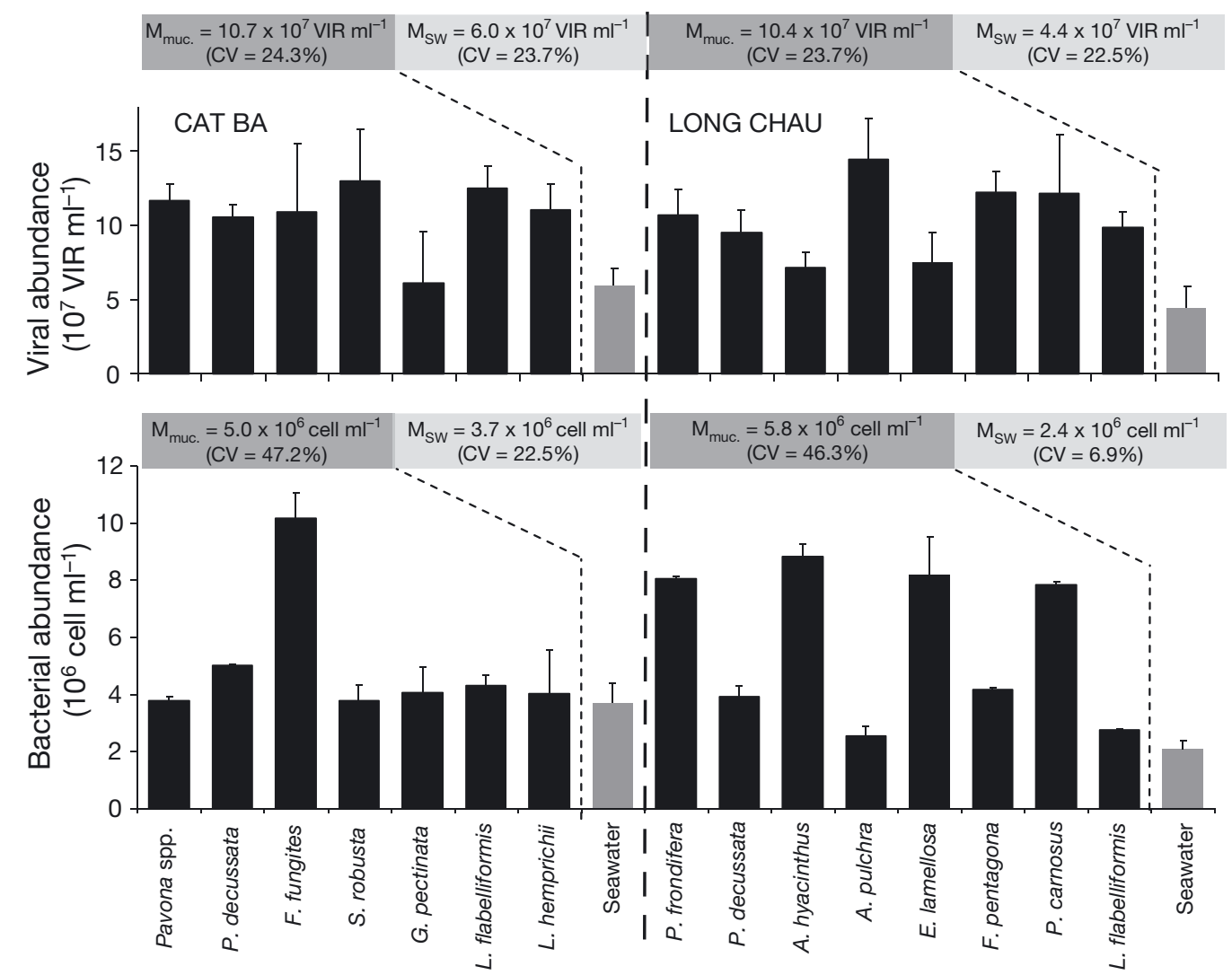

Fig. 2. Viral and bacterial abundances in coral mucus and seawater samples in Cat Ba and Long Chau Islands. $M_{\text {muc.: }}$ mean value obtained for the mucus samples; $\mathrm{M}_{\mathrm{SW}}$ : mean values obtained for the seawater samples; VIR: viral abundance. See 'Materials and methods' for full genus names 
Table 2. One-way ANOVA of the different viral and bacterial parameters measured in the coral mucus and seawater samples at Cat $\mathrm{Ba}$ and Long Chau stations. The inter-site comparison could only be realized from the results obtained for the 2 species that were common to both sites (i.e. Lobophyllia flabelliformis and Pavona decussata). BAC: bacterial abundance; VIR: viral abundance; VBR: virus-to-bacteria ratio; OTU: operational taxonomic unit. Bold: significantly different at $\mathrm{p}<0.05$

\begin{tabular}{|c|c|c|c|c|}
\hline \multirow[t]{2}{*}{ Parameter } & \multirow{2}{*}{$\begin{array}{l}\text { Mucus/ } \\
\text { seawater } \\
\text { (p-value) }\end{array}$} & \multicolumn{3}{|c|}{ - Cat Ba/Long Chau (p-value) } \\
\hline & & $\begin{array}{c}\text { Mucus } \\
\text { (L. flabelliformis) }\end{array}$ & $\begin{array}{c}\text { Mucus } \\
\text { (P. decussata) }\end{array}$ & Seawater \\
\hline $\mathrm{BAC}$ & $1.92 \times 10^{-9}$ & 0.106 & 0.059 & $5.12 \times 10^{-6}$ \\
\hline VIR & $3.05 \times 10^{-9}$ & 0.285 & 0.459 & 0.023 \\
\hline VBR & $<0.0005$ & 0.376 & 0.860 & 0.042 \\
\hline OTU & 0.014 & 0.309 & 0.492 & 0.047 \\
\hline Cocci (\%) & 0.452 & 0.023 & 0.143 & 0.174 \\
\hline $\operatorname{Rod}(\%)$ & 0.002 & 0.693 & $<0.01$ & 0.010 \\
\hline Curved (\%) & 0.283 & 0.823 & 0.323 & 0.781 \\
\hline Filaments (\%) & 0.007 & 0.173 & 0.588 & 0.429 \\
\hline
\end{tabular}

species that were common at both sites (ie Pavona decussata and Lobophyllia flabelliformis), the concentrations of viral epibionts did not show any significant differences between Cat Ba and Long Chau. On the contrary, the abundance of planktonic viruses was significantly higher in Cat Ba (mean $=6.0 \times 10^{7}$ viruses $\mathrm{ml}^{-1}, \mathrm{p}<0.05$ ) than in preserved Long Chau waters $\left(\right.$ mean $=4.4 \times 10^{7}$ viruses $\mathrm{ml}^{-1}, \mathrm{p}<0.05$ ) (Fig. 2, Table 2).

As for viruses, the abundance of bacterial communities was, on average, also higher in the coral mucus samples than in the surrounding seawater (Fig. 2, Table 2); although the differences were lower than with viruses, and mostly resulting from the high concentrations measured in Fungia fungites in Cat Ba or A. hyacinthus in Long Chau (Fig. 2). The inter-species variability in the abundance of mucosal bacteria (coefficient of variation
$[\mathrm{CV}]=46.7 \%$ ) was much higher than for their planktonic counterparts $(\mathrm{CV}=14.7 \%)$ and for the mucosal viruses $(\mathrm{CV}=23.0 \%)$ (Fig. 2). As was the case for viruses, the abundance of epibiotic bacteria in $P$. decussata and L. flabelliformis did not significantly differ between the 2 sampled sites. Conversely, planktonic bacterial cells were significantly more abundant in Cat $\mathrm{Ba}$ $\left(\right.$ mean $=3.7 \times 10^{6}$ cells $\mathrm{ml}^{-1}, \mathrm{p}<$ 0.05) than Long Chau (mean $=2.4 \times$ $10^{6}$ cells $\mathrm{ml}^{-1}, \mathrm{p}<0.05$ ) (Fig. 2, Table 2). Finally, regardless of the site, a significant and positive correlation was found between viral and bacterial abundances in coral mucus samples (Table 3).

At both sites, the virus-to-bacteria ratio (VBR) was also consistently and significantly higher in the mucus (mean at Cat Ba $\left[\mathrm{m}_{\mathrm{CB}}\right]=24.2 \pm 40.1 \%$; mean at Long Chau $\left[\mathrm{m}_{\mathrm{LC}}\right]=24.1 \pm 68.8 \%$ ) than seawater samples $\left(\mathrm{m}_{\mathrm{CB}}=15.4 \pm 10.5 \% ; \mathrm{m}_{\mathrm{LC}}=16.4 \pm 32.8 \%\right)$ (ANOVA, $\mathrm{p}<0.05$ ). The inter-site comparison of the VBR in P. decussata and L. flabelliformis revealed higher values in the seawater in Long Chau than Cat $\mathrm{Ba}$, whereas no significant difference could be found for the mucosal communities (Table 2).

\section{Bacterial morphotypes}

Among the 4 main cell morphotypes studied, only rods and filamentous forms were significantly more abundant in mucus than in seawater samples (Fig. 3, Table 2). The respective proportions of cocci and rod-

Table 3. Pearson correlation coefficients between viral and bacterial parameters for the totality of coral mucus samples (Cat Ba and Long Chau). BAC: bacterial abundance; VIR: viral abundance; VBR: virus-to-bacteria ratio; OTU: operational taxonomic unit; C-VIB: culturable Vibrionaceae; C-BAC: culturable heterotrophic bacteria. Bold: Significant at p $<0.05$

\begin{tabular}{|lrrrrrrrrr|}
\hline Variable & BAC & VIR & VBR & OTU & C-VIB & C-BAC & Cocci & Rods & Curved \\
\hline BAC & $\mathbf{1}$ & & & & & & & \\
VIR & $\mathbf{0 . 5 0 0}$ & $\mathbf{1}$ & & & & & & \\
VBR & 0.049 & -0.129 & $\mathbf{1}$ & & & & & \\
OTU & 0.169 & 0.187 & -0.133 & $\mathbf{1}$ & & & & \\
C-VIB & -0.442 & -0.374 & -0.401 & -0.366 & $\mathbf{1}$ & & & \\
C-BAC & -0.328 & -0.063 & 0.275 & $\mathbf{- 0 . 5 5 5}$ & 0.111 & $\mathbf{1}$ & & \\
Cocci & $\mathbf{0 . 6 2 3}$ & 0.032 & -0.035 & 0.381 & -0.311 & -0.423 & $\mathbf{1}$ & \\
Rods & -0.016 & -0.246 & 0.092 & 0.162 & -0.084 & -0.211 & 0.000 & $\mathbf{1}$ & \\
Curved & 0.025 & -0.238 & -0.439 & 0.060 & 0.230 & -0.473 & 0.285 & 0.433 & $\mathbf{1}$ \\
Filaments & -0.459 & -0.441 & -0.400 & 0.072 & 0.326 & -0.205 & 0.223 & 0.125 & $\mathbf{0 . 6 8 7}$ \\
\hline
\end{tabular}



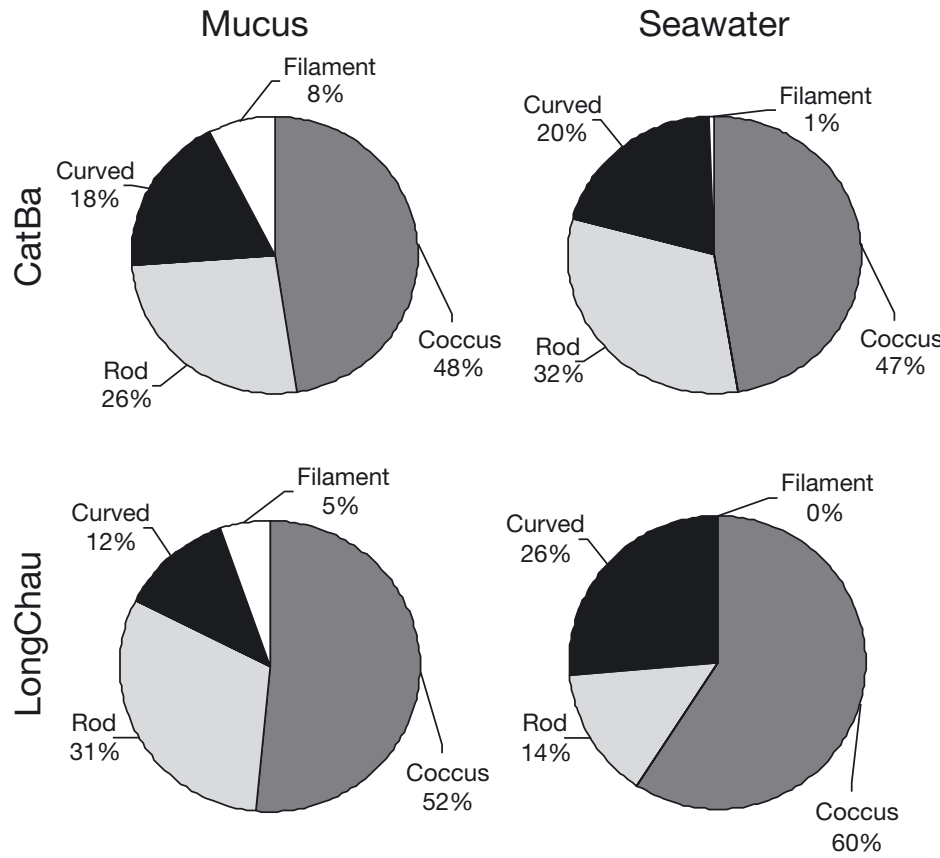

Fig. 3. Distribution of the main bacterial morphotypes in coral mucus and seawater samples in Cat Ba and Long Chau Islands like bacteria in the mucus of $L$. flabelliformis and $P$. decussata exhibited significant differences between Cat $\mathrm{Ba}$ and Long Chau (Table 2).

\section{Culturable prokaryotes}

The average concentration of C-BAC was 5.9- and 12.5-fold more elevated in the mucus than in seawater samples in Cat Ba and Long Chau, respectively (Fig. 4). For C-VIB, the difference between mucus and seawater was even greater, reaching 90and 170-fold higher in mucus in Cat $\mathrm{Ba}$ and Long Chau, respectively (Fig. 4). A significant correlation was found between the abundance of C-BAC and the number of OTUs in the different coral species (Table 3). In contrast, C-VIB concentrations were not correlated with any of the other measured parameters.

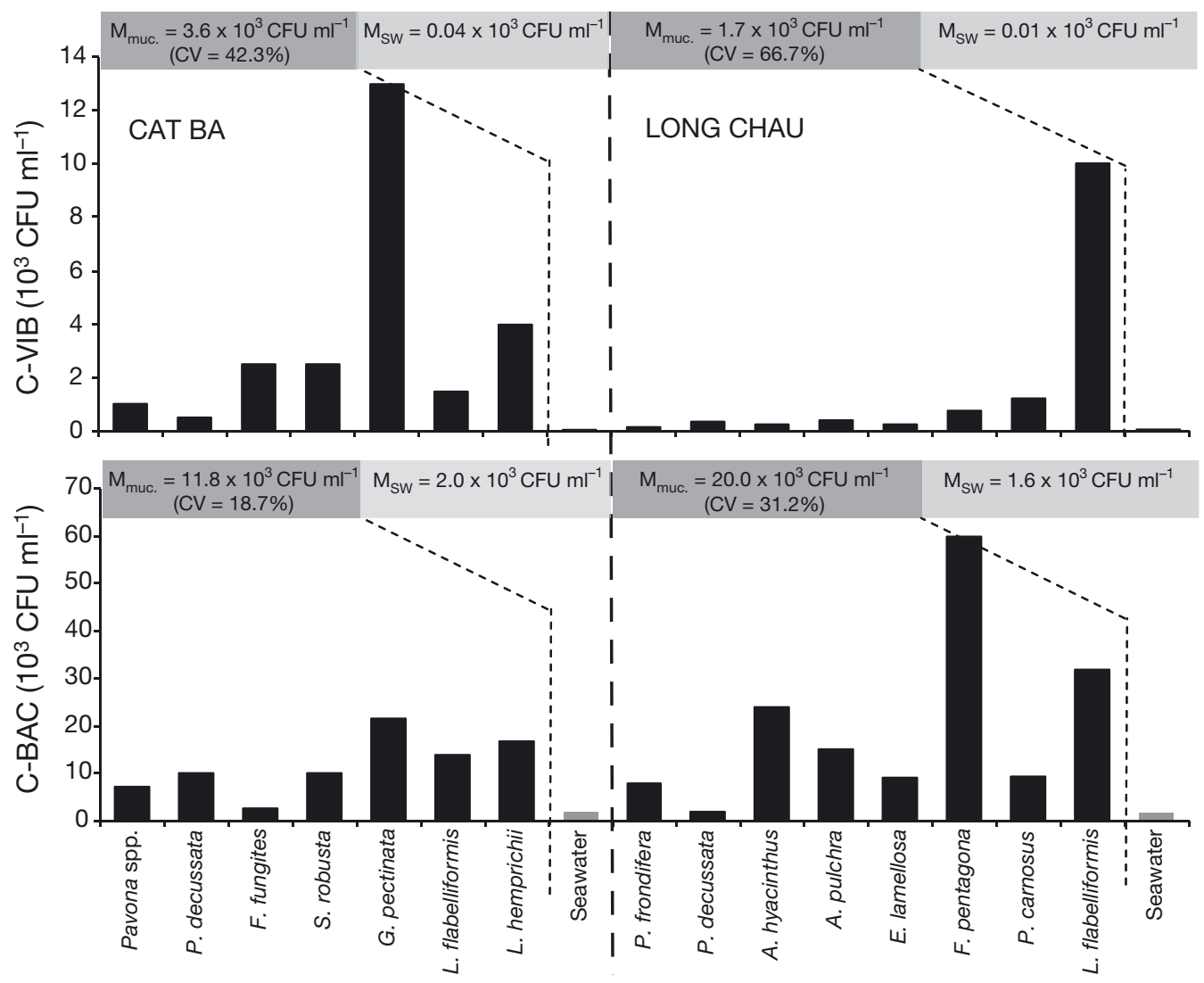

Fig. 4. Abundance of culturable heterotrophic bacteria (C-BAC) and culturable Vibrionaceae (C-VIB) in coral mucus and seawater samples in Cat Ba and Long Chau Islands. CFU: colony-forming units 


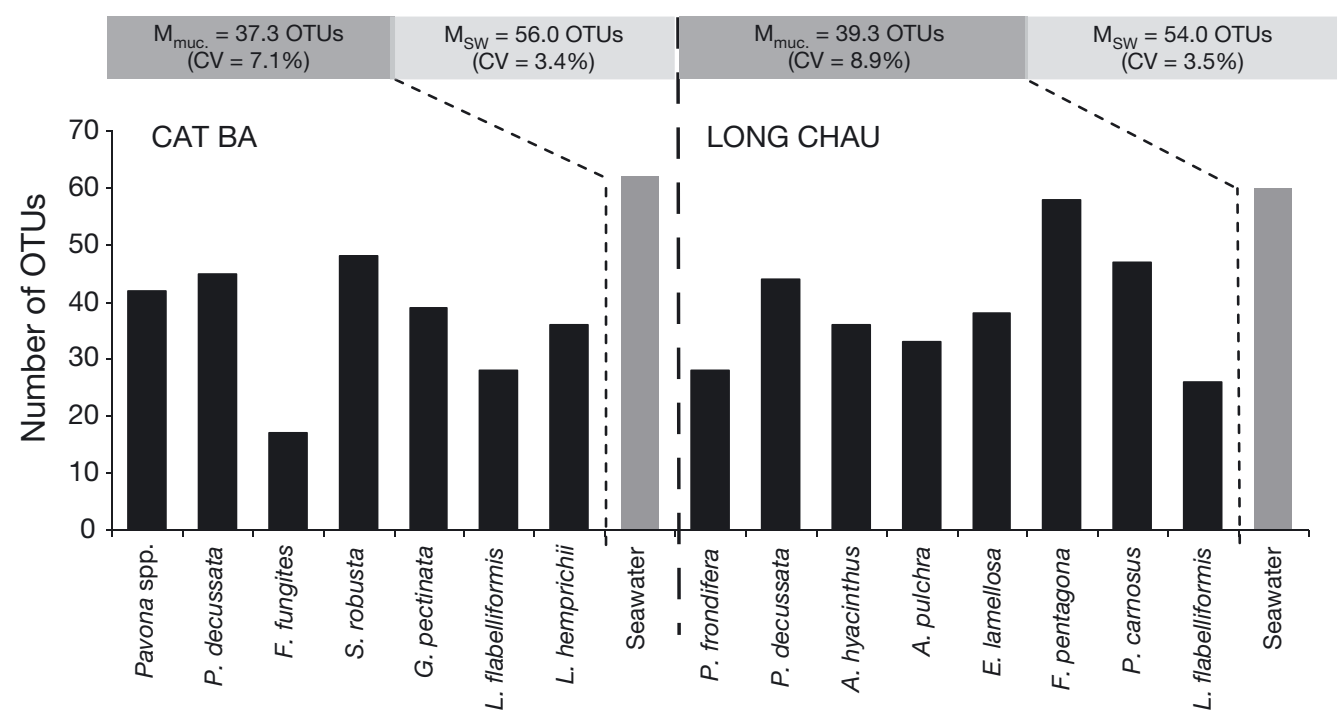

Fig. 5. Number of operational taxonomic units (OTUs) measured in coral mucus and seawater samples in Cat Ba and Long Chau Islands

\section{DGGE-based estimates of prokaryotic community genetic diversity}

Unlike the majority of the other parameters, the number of OTUs obtained by DGGE was consistently and significantly lower in mucus $\left(\mathrm{m}_{\mathrm{CB}}=37.3 ; \mathrm{m}_{\mathrm{LC}}=\right.$ 39.3) than in seawater $\left(\mathrm{m}_{\mathrm{CB}}=56.0 ; \mathrm{m}_{\mathrm{LC}}=54.0\right)$ (Fig. 5, Table 2). Nonetheless, there was no significant difference between the 2 studied sites for both L. flabelliformis and $P$. decussata (Table 2). The cluster analysis of DGGE profiles revealed a clear root discrimination of the community composition between planktonic and epibiotic bacteria (Fig. 6). Surprisingly, P. decussata exhibited the longest distance with seawater samples in Cat Ba and the shortest in Long Chau, suggesting that the intraspecies variability in OTU composition can be relatively high among coral species
(Fig. 6). The PERMANOVA revealed a higher level of variability in bacterial community composition between all the different coral species than between the 2 sites (PERMANOVA, $\mathrm{p}=0.098$ ). Regarding the 2 common species (P. decussata and L. flabelliformis), their bacterial community composition was not significantly different between the 2 sites (PERMANOVA, $\mathrm{p}=0.950)$.

\section{DISCUSSION}

\section{Planktonic versus epibiotic abundance of viruses and bacteria}

In the present study, viral abundance was more than twice as high in the mucus of the different coral
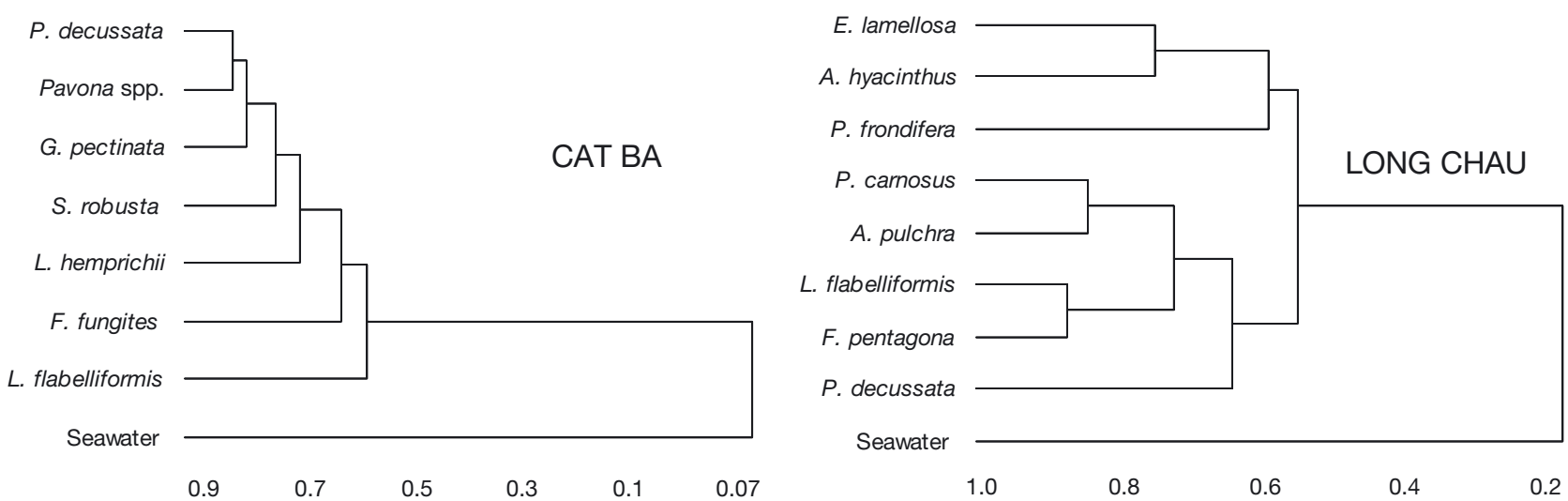

Fig. 6. Similarity dendograms of the DGGE band patterns obtained with an agglomerative hierarchical clustering analysis from the mucus and seawater samples of Cat Ba and Long Chau 
species than in the surrounding water. Similar observations have been previously reported from cultured (Leruste et al. 2012) or in situ corals (Davy et al. 2006, Patten et al. 2008, Nguyen-Kim et al. 2015). There are several explanations for such levels of abundance, such as the highly adhesive property of coral mucus. From the recent report of Barr et al. (2013b), we know that phage capsids and their lg-like protein domains have strong chemical affinities with the mucin-glycoproteins of the mucus, resulting in viral enrichment in this organic layer. Viral proliferation could also be stimulated by the high nutritive quality of mucus promoting the fast growth of their bacteria hosts. The positive and significant correlation found between viral and bacterial epibionts supports the idea that most of the viral hosts were bacteria, which is in line with previous reports (Vega Thurber et al. 2009, Nguyen-Kim et al. 2014). Mucus is a biogel composed primarily of carbohydrates, which contribute to around $80 \%$ of the chemical composition (Ducklow \& Mitchell 1979, Bansil \& Turner 2006). Glucose is considered the most common carbohydrate component in coral mucus (Wild et al. 2010) and is recognized as a crucial energy source for most bacterial cells, which helps to explain why coral mucus is populated by active and fast-growing bacteria (Ritchie \& Smith 2004, Brown \& Bythell 2005). In the aquatic environment, viral activity and abundance are generally tightly coupled with the physiological state and abundance of their hosts (Weinbauer 2004, Maurice et al. 2010). Highly active cells typically allow a rapid and efficient completion of viral lytic cycles (Maurice et al. 2013), and this was the case in coral mucus, where bacterial respiring activity (as measured with the 5-cyano-2,3-ditoyl tetrazolium chloride [CTC] approach) was found to be much higher than in the water column (NguyenKim et al. 2014). Levels of abundance were also much higher for epibiotic total bacteria, cultivable bacteria and vibrio, compared to their planktonic counterparts, which corroborates previous findings (Ritchie $\&$ Smith 2004) and helps explain the large occurrence of phages in mucus.

The bacterial community diversity revealed by microscopic observations and phylogenetic analysis also showed large differences between coral epibionts and planktonic cells, as reported on several occasions (Rohwer et al. 2002, Ritchie \& Smith 2004, Kvennefors et al. 2010, Carlos et al. 2013). On average, rods and filamentous cells were more abundant in mucus. Prokaryotes are typically attracted by hot spots of high nutritive values, and specific shapes also give cells greater access to nutrients (Young
2006). With similar volumes, filament and rod morphotypes show a higher total surface area compared to cocci. As hypothesized by Steinberger et al. (2002), filamentation may benefit cells attached to a surface, because it increases that specific surface area in direct contact with the medium (coral mucus in our case). The DGGE analyses also confirmed that coral mucus represents a selective medium that harbors a unique consortium of bacteria, which is structurally different from that of the surrounding water (Rohwer et al. 2001, Koren \& Rosenberg 2006, Carlos et al. 2013). Contrary to previous findings for most of the microbial parameters, the number of OTUs was higher in the seawater $($ mean $=55)$ than in the mucus (mean $=38.3$ ). In the latter, these numbers were comparable to those reported in the literature by other studies: 41 bands for Montastraea faveolata (Guppy \& Bythell 2006); 44 bands for Acropora millepora (Kvennefors et al. 2010); and 25 bands on average for Madracis decactis, Mussismilia hispida, Palythoa caribaeorum and Tubastraea coccinea (Carlos et al. 2013). Such discrepancies between mucus and seawater may be naturally attributed to the specific chemical composition of mucus, which is highly selective (Brown \& Bythell 2005), but also to the antimicrobial properties of the former, which can typically inhibit the bacterial growth of certain phylogenetic groups or species and ensure the selection and maintenance of a limited number of active bacterial symbionts (Kvennefors et al. 2012).

\section{Coral inter-species variability of bacterial and viral communities}

In our study, all of the measured parameters exhibited large variations between the different coral species. Coral-associated bacterial community composition has long been shown to be species specific (Rohwer et al. 2002, Tremblay et al. 2011, Morrow et al. 2012), but viral and bacterial abundances can also strongly differ between coral species (Leruste et al. 2012, Nguyen-Kim et al. 2014, 2015). Such differences have been partly linked to the species-specific chemical composition of coral mucus (Ducklow \& Mitchell 1979, Meikle et al. 1988, Krediet et al. 2013). Another potential explanation is the existence of large variations in mucus production, both within and between species, which could also be linked to the type and intensity of stress imposed on corals, and which may result in the dilution/concentration of the particles in the gel (Naumann et al. 2010, Cod- 
deville et al. 2011). Alternatively, the substantial antimicrobial activities measured in coral mucus (Kvennefors et al. 2012) represent another strong biotic regulator of bacterial proliferation, which may differ from one species to the other (Shnit-Orland \& Kushmaro 2008, Krediet et al. 2013). Finally, all these intrinsic determinants of bacterial abundance are suspected to indirectly impact the production and distribution of their viral parasites. The speciesspecific viscosity of this biogel (Brown \& Bythell 2005) could also potentially influence the movement of viruses and their chance to encounter and infect bacteria within coral mucus.

\section{Inter-site comparison of viral and bacterial traits in coral mucus}

In the ocean's water column, nutrient availability represents one of the main determinants of bacterial growth and viability. However, the influence of trophic environment on bacterial epibionts of corals remains unclear. Although the presence of high concentrations of inorganic nutrients has been shown to promote coral diseases (Fabricius 2005, Voss \& Richardson 2006) the underlying mechanisms have not yet been elucidated. Also, to date, the abundance of mucosal cells has not been evaluated and compared in in situ biomes of contrasting trophic regime.

In this study, a total of 14 different coral species were sampled, but only 2 (i.e. P. decussata and L. flabelliformis) were common at both sites; being also capable of producing a sufficient amount of mucus for the various analyses, these species allowed us to make the inter-site comparison of coral-associated viral and bacterial traits. Thus, this comparison should be taken with caution and clearly needs further investigation. However, although bacterial communities are species-specific (Rohwer et al. 2002, Ceh et al. 2011), such a low-resolution comparison still remains of interest, providing a global snapshot of bacterial and viral ecological traits in scleractinians.

Surprisingly in our study, despite important discrepancies in the concentrations of nutrients (nitrate and phosphate), dissolved organic carbon and chl a between the 2 different sampling stations (see also Faxneld et al. 2011), no significant differences could be detected for either bacterial or viral abundances measured in $P$. decussata and L. flabelliformis (see Table 2). Interestingly, like for their abundance, epibiotic bacteria did not show any significant difference in their community composition between these 2 coral species (PERMANOVA test). Again, given the low replication of coral samples, the lack of significant differences should be interpreted with prudence. Coral-microbe relationships are susceptible to sudden rises in organic matter inputs (Voss \& Richardson 2006, Vega Thurber et al. 2009). For example, an experimental increase in dissolved organic carbon concentrations stimulated the growth rate of microbes living on corals' superficial layer by an order of magnitude (Kline et al. 2006). Numerically, the absence of significant difference in these 2 species could be explained by the recently documented ability of corals to shed bacteria (Garren \& Azam 2012). By using high-speed laser scanning confocal microscopy on live corals, these authors observed that scleractinians can get rid of excess of bacterial cells during times of organic matter stress. In other words, this mechanism may counteract bacterial growth stimulated by organic inputs and may potentially help explain the equivalent levels of abundance of epibiotic viruses and prokaryotes in both Cat Ba and Long Chau. However, we have no direct evidence for this to occur in the present study. Another recent study on cold water corals reported that an experimental enrichment of viral and bacterial abundance in surrounding water did increase the abundances in the coelenteron but not in the mucus of corals, indicating some sort of ecological stability of epibiotic microbes (Weinbauer et al. 2012). Alternatively, coral-associated bacterial communities have also been recognized for their ecological adaptation, being capable of strong physiological and genetic adjustments to cope with environmental disturbances and to ultimately ensure coral viability (Reshef et al. 2006, Rosenberg et al. 2009, Bourne et al. 2011). Finally, the maintenance of relatively stable abundances and phylogenetic composition of epibiotic bacteria and viruses may be crucial for corals to avoid the excessive accumulation of these particles in mucus beyond a threshold that would otherwise threaten the balance between corals and their associated microbiota. Further investigations are now necessary to gain a deeper insight into the molecular and ecological processes allowing corals to regulate the abundance of their symbionts and how such symbionts can also auto-adjust their abundance in the mucus. Overall, our results provide support for the hypothesis that coral mucus represents a confined environment for an adapted consortium of bacterial cells (and their viral parasites) whose development seems preserved from some variability of the trophic characteristics of the water column. 
Acknowledgements. The work was supported in part by grants from the Vietnam Academy of Science and Technology (VAST) with code project VAST 07.03/11-12, by the TOTAL Foundation (PATRICIA project) and by the MOST (Black Carbon project). We thank the MARBEC Research Unit in Montpellier, the Institute of Biotechnology and the National Institute of Health and Epidemiology of Hanoi for laboratory facilities.

\section{LITERATURE CITED}

Alagely A, Krediet CJ, Ritchie KB, Teplitski M (2011) Signaling-mediated cross-talk modulates swarming and biofilm formation in a coral pathogen Serratia marcescens. ISME J 5:1609-1620

Anderson MJ (2001) A new method for non-parametric multivariate analysis of variance. Austral Ecol 26:32-46

Anderson MJ (2006) Distance-based tests for homogeneity of multivariate dispersions. Biometrics 62:245-253

Apprill A, Marlow HQ, Martindale MQ, Rappé MS (2012) Specificity of associations between bacteria and the coral Pocillopora meandrina during early development. Appl Environ Microbiol 78:7467-7475

Arotsker L, Siboni N, Ben-Dov E, Kramarsky-Winter E, Loya Y, Kushmaro A (2009) Vibrio sp. as a potentially important member of the black band disease (BBD) consortium in Favia sp. corals. FEMS Microbiol Ecol 70:515-524

Bansil R, Turner BS (2006) Mucin structure, aggregation, physiological functions and biomedical applications. Curr Opin Colloid Interface Sci 11:164-170

- Barr JJ, Auro R, Furlan M, Whiteson KL and others (2013a) Bacteriophage adhering to mucus provide a nonhost-derived immunity. Proc Natl Acad Sci USA 110: 10771-10776

Barr JJ, Youle M, Rohwer F (2013b) Innate and acquired bacteriophage-mediated immunity. Bacteriophage 3:e25857

> Ben-Haim Y, Thompson F, Thompson C, Cnockaert M, Hoste B, Swings J, Rosenberg E (2003) Vibrio coralliilyticus sp. nov., a temperature-dependent pathogen of the coral Pocillopora damicornis. Int J Syst Evol Microbiol 53: 309-315

> Bettarel Y, Bouvier T, Nguyen HK, Thu PT (2014) The versatile nature of coral-associated viruses. Environ Microbiol, doi:10.1111/1462-2920.12579

> Bourne DG, Garren M, Work TM, Rosenberg E, Smith GW, Harvell CD (2009) Microbial disease and the coral holobiont. Trends Microbiol 17:554-562

Bourne DG, Muirhead A, Sato Y (2011) Changes in sulfatereducing bacterial populations during the onset of black band disease. ISME J 5:559-564

Brown BE, Bythell JC (2005) Perspectives on mucus secretion in reef corals. Mar Ecol Prog Ser 296:291-309

Cárdenas A, Rodriguez RL, Pizarro V, Cadavid LF, ArevaloFerro C (2012) Shifts in bacterial communities of two Caribbean reef-building coral species affected by white plague disease. ISME J 6:502-512

> Carlos C, Torres TT, Ottoboni LM (2013) Bacterial communities and species-specific associations with the mucus of Brazilian coral species. Sci Rep 3:1624

> Ceh J, Van Keulen M, Bourne DG (2011) Coral-associated bacterial communities on Ningaloo Reef, Western Australia. FEMS Microbiol Ecol 75:134-144

Cervino JM, Thompson FL, Gomez Gil B, Lorence EA and others (2008) The Vibrio core group induces yellow band disease in Caribbean and Indo Pacific reef building corals. J Appl Microbiol 105:1658-1671

Coddeville B, Maes E, Ferrier-Pagès C, Guerardel Y (2011) Glycan profiling of gel forming mucus layer from the scleractinian symbiotic coral Oculina arbuscula. Biomacromolecules 12:2064-2073

> Cole AJ, Lawton RJ, Pratchett MS, Wilson SK (2011) Chronic coral consumption by butterflyfishes. Coral Reefs 30: 85-93

> Correa AMS, Welsh RM, Vega Thurber RL (2013) Unique nucleocytoplasmic dsDNA and +ssRNA viruses are associated with the dinoflagellate endosymbionts of corals. ISME J 7:13-27

> Davy JE, Patten NL (2007) Morphological diversity of viruslike particles within the surface microlayer of scleractinian corals. Aquat Microb Ecol 47:37-44

Davy SK, Burchett SG, Dale AL, Davies P and others (2006) Viruses: agents of coral disease? Dis Aquat Org 69: 101-110

Ducklow HW, Mitchell R (1979) Composition of mucus released by coral reef coelenterates. Limnol Oceanogr 24:706-714

Eaton AD, Clesceri LS, Greenberg AR (1995) Standard methods for the examination of water and waste-water, 19th edn. American Public Health Association, Washington, DC

Fabricius KE (2005) Effects of terrestrial runoff on the ecology of corals and coral reefs: review and synthesis. Mar Pollut Bull 50:125-146

Faxneld S, Jörgensen TL, Nguyen ND, Nyström M, Tedengren $M$ (2011) Differences in physiological response to increased seawater temperature in nearshore and offshore corals in northern Vietnam. Mar Environ Res 71: 225-233

Garren M, Azam F (2012) Corals shed bacteria as a potential mechanism of resilience to organic matter enrichment. ISME J 6:1159-1165

Gomez-Gil B, Soto-Rodriguez S, García-Gasca A, Roque A, Vazquez-Juarez R, Thompson FL, Swings J (2004) Molecular identification of Vibrio harveyi-related isolates associated with diseased aquatic organisms. Microbiology 150:1769-1777

Goulet TL (2006) Most corals may not change their symbionts. Mar Ecol Prog Ser 321:1-7

> Guppy R, Bythell JC (2006) Environmental effects on bacterial diversity in the surface mucus layer of the reef coral Montastraea faveolata. Mar Ecol Prog Ser 328:133-142

> Harvell CD, Mitchell CE, Ward JR, Altizer S, Dobson AP, Ostfeld RS, Samuel MD (2002) Climate warming and disease risks for terrestrial and marine biota. Science 296: 2158-2162

Hoeksema BW, Scott C, True JD (2013) Dietary shift in corallivorous Drupella snails following a major bleaching event at Koh Tao, Gulf of Thailand. Coral Reefs 32: 423-428

> Holm-Hansen O, Lorenzen CJ, Holmes RW, Strickland JDH (1965) Fluorometric determination of chlorophyll. J Cons Int Explor Mer 30:3-15

Hossain M, Mahmud I, Parvez S, Cho HM (2013) Impact of current density, operating time and $\mathrm{pH}$ of textile wastewater treatment by electrocoagulation process. Environ Eng Res 18:157-161

> Hughes TP, Baird AH, Bellwood DR, Card M and others (2003) Climate change, human impacts, and the resilience of coral reefs. Science 301:929-933 
Jardillier L, Bettarel Y, Richardot M, Bardot C, Amblard C, Sime-Ngando T, Debroas D (2005) Effects of viruses and predators on prokaryotic community composition. Microb Ecol 50:557-569

Kayal M, Vercelloni J, Lison de Loma T, Bosserelle P and others (2012) Predator crown-of-thorns starfish (Acanthaster planci) outbreak, mass mortality of corals, and cascading effects on reef fish and benthic communities. PLoS ONE 7:e47363

Kline DI, Kuntz NM, Breitbart M, Knowlton N, Rohwer F (2006) Role of elevated organic carbon levels and microbial activity in coral mortality. Mar Ecol Prog Ser 314: 119-125

Koren O, Rosenberg E (2006) Bacteria associated with mucus and tissues of the coral Oculina patagonica in summer and winter. Appl Environ Microbiol 72: 5254-5259

> Krediet CJ, Ritchie KB, Paul VJ, Teplitski M (2013) Coralassociated micro-organisms and their roles in promoting coral health and thwarting diseases. Proc R Soc Lond B 280:20122328

Kushmaro A, Banin E, Loya Y, Stackebrandt E, Rosenberg E (2001) Vibrio shiloi sp. nov., the causative agent of bleaching of the coral Oculina patagonica. Int J Syst Evol Microbiol 51:1383-1388

Kvennefors ECE, Sampayo E, Ridgway T, Barnes AC, Hoegh-Guldberg $O$ (2010) Bacterial communities of two ubiquitous great barrier reef corals reveals both site- and species-specificity of common bacterial associates. PLoS ONE 5:e10401

Kvennefors EC, Sampayo E, Kerr C, Vieira G, Roff G, Barnes AC (2012) Regulation of bacterial communities through antimicrobial activity by the coral holobiont. Microb Ecol 63:605-618

Lentz JA, Blackburn JK, Curtis AJ (2011) Evaluating patterns of a white-band disease (WBD) outbreak in Acropora palmata using spatial analysis: a comparison of transect and colony clustering. PLoS ONE 6:e21830

> Leruste A, Bouvier T, Bettarel Y (2012) Enumerating viruses in coral mucus. Appl Environ Microbiol 78:6377-6379

> Lesser MP, Bythell JC, Gates RD, Johnstone RW, HoeghGuldberg O (2007) Are infectious diseases really killing corals? Alternative interpretations of the experimental and ecological data. J Exp Mar Biol Ecol 346:36-44

Lohr J, Munn CB, Wilson WH (2007) Characterization of a latent virus-like infection of symbiotic zooxanthellae. Appl Environ Microbiol 73:2976-2981

> Marhaver KL, Edwards RA, Rohwer F (2008) Viral communities associated with healthy and bleaching corals. Environ Microbiol 10:2277-2286

> Maurice CF, Bouvier T, Comte J, Guillemette F, del Giorgio PA (2010) Seasonal variations of phage life strategies and bacterial physiological states in three northern temperate lakes. Environ Microbiol 12:628-641

- Maurice CF, Bouvier C, de Wit R, Bouvier T (2013) Linking the lytic and lysogenic bacteriophage cycles to environmental conditions, host physiology and their variability in coastal lagoons. Environ Microbiol 15:2463-2475

Meikle P, Richards GN, Yellowlees D (1988) Structural investigations on the mucus from six species of coral. Mar Biol 99:187-193

Morrow KM, Moss AG, Chadwick NE, Liles MR (2012) Bacterial associates of two caribbean coral species reveal species-specific distribution and geographic variability. Appl Environ Microbiol 78:6438-6449
Muyzer G, De Waal EC, Uitterlinden AG (1993) Profiling of complex microbial populations by denaturing gradient gel electrophoresis analysis of polymerase chain reaction-amplified genes coding for 16S rRNA. Appl Environ Microbiol 59:695-700

Naumann MS, Richter C, el-Zibdah M, Wild C (2009) Coral mucus as an efficient trap for picoplanktonic cyanobacteria: implications for pelagic-benthic coupling in the reef ecosystem. Mar Ecol Prog Ser 385:65-76

> Nguyen-Kim H, Bouvier T, Bouvier C, Doan-Nhu H and others (2014) High occurrence of viruses in the mucus layer of scleractinian corals. Environ Microbiol Rep 6: 675-682

Nguyen-Kim H, Bettarel Y, Bouvier T, Bouvier C and others (2015) Coral mucus is a hot spot for viral infections. Appl Environ Microbiol 81:5773-5783

> Ovreås L, Forney L, Daae FL, Torsvik V (1997) Distribution of bacterioplankton in meromictic Lake Saelenvannet, as determined by denaturing gradient gel electrophoresis of PCR-amplified gene fragments coding for 16S rRNA. Appl Environ Microbiol 63:3367-3373

Pandolfi JM, Bradbury RH, Sala E, Hughes TP and others (2003) Global trajectories of the long-term decline of coral reef ecosystems. Science 301:955-958

> Pandolfi JM, Connolly SR, Marshall DJ, Cohen AL (2011) Projecting coral reef futures under global warming and ocean acidification. Science 333:418-422

> Patel A, Noble RT, Steele JA, Schwalbach MS, Hewson I, Fuhrman JA (2007) Virus and prokaryote enumeration from planktonic aquatic environments by epifluorescence microscopy with SYBR Green I. Nat Protoc 2: 269-276

> Patten NL, Harrison PL, Mitchell JG (2008) Prevalence of virus-like particles within a staghorn scleractinian coral (Acropora muricata) from the Great Barrier Reef. Coral Reefs 27:569-580

Pollock FJ, Lamb JB, Field SN, Heron SF and others (2014) Sediment and turbidity associated with offshore dredging increase coral disease prevalence on nearby reefs. PLoS ONE 9:e102498

Reche I, Pulido-Villena E, Morales-Baquero R, Casamayor EO (2005) Does ecosystem size determine aquatic bacterial richness? Ecology 86:1715-1722

Reshef L, Koren O, Loya Y, Zilber-Rosenberg I, Rosenberg E (2006) The coral probiotic hypothesis. Environ Microbiol 8:2068-2073

Ritchie K, Smith G (2004) Microbial communities of coral surface mucopolysaccharide layers. In: Rosenberg E, Loya Y (eds) Coral health and disease. Springer, Heidelberg, p 259-263

Rohwer F, Breitbart M, Jara J, Azam F, Knowlton N (2001) Diversity of bacteria associated with the Caribbean coral Montastraea franksi. Coral Reefs 20:85-91

Rohwer F, Seguritan V, Azam F, Knowlton N (2002) Diversity and distribution of coral-associated bacteria. Mar Ecol Prog Ser 243:1-10

Rosenberg E, Kushmaro A, Kramarsky-Winter E, Banin E, Yossi L (2009) The role of microorganisms in coral bleaching. ISME J 3:139-146

Rypien KL, Ward JR, Azam F (2010) Antagonistic interactions among coral-associated bacteria. Environ Microbiol 12:28-39

Shnit-Orland M, Kushmaro A (2008) Coral mucus bacteria as a source for antibacterial activity. Proc 11th Int Coral Reef Symp, Lauderdale, FL, 7-11 July 2008, 1:261-263 
Shnit-Orland M, Sivan A, Kushmaro A (2012) Antibacterial activity of Pseudoalteromonas in the coral holobiont. Microb Ecol 64:851-859

Smith GW, Hayasaka SS (1982) Nitrogenase activities associated with Zostera marina from a North Carolina estuary. Can J Microbiol 28:448-451

Steinberger RE, Allen AR, Hansma HG, Holden PA (2002) Elongation correlates with nutrient deprivation in Pseudomonas aeruginosa unsaturated biofilms. Microb Ecol 43:416-423

Suttle CA (2007) Marine viruses - major players in the global ecosystem. Nat Rev Microbiol 5:801-812

Thanh T, Saito Y, Huy D, Nguyen V, Ta T, Tateishi M (2004) Regimes of human and climate impacts on coastal changes in Vietnam. Reg Environ Change 4:49-62

Tremblay P, Weinbauer MG, Rottier C, Guérardel Y, Nozais $C$, Ferrier-Pagès C (2011) Mucus composition and bacterial communities associated with the tissue and skeleton of three scleractinian corals maintained under culture conditions. J Mar Biol Assoc UK 91:649-657

Uchiyama H (2000) Distribution of Vibrio species isolated from aquatic environments with TCBS agar. Environ Health Prev Med 4:199-204

Van Oppen MJ, Leong JA, Gates RD (2009) Coral-virus interactions: a double-edged sword? Symbiosis 47:1-8

Vega Thurber R, Correa A (2011) Viruses of tropical stony corals. J Exp Mar Biol Ecol 408:102-113

> Vega Thurber R, Barott KL, Hall D, Liu H and others (2008) Metagenomic analysis indicates that stressors induce

Editorial responsibility: Curtis Suttle,

Vancouver, Canada production of herpes-like viruses in the coral Porites compressa. Proc Natl Acad Sci USA 105:18413-18418

> Vega Thurber R, Willner-Hall D, Rodriguez-Mueller B, Desnues C and others (2009) Metagenomic analysis of stressed coral holobionts. Environ Microbiol 11:2148-2163

Voss J, Richardson L (2006) Nutrient enrichment enhances black band disease progression in corals. Coral Reefs 25: 569-576

Weinbauer MG (2004) Ecology of prokaryotic viruses. FEMS Microbiol Rev 28:127-181

Weinbauer MG, Ogier J, Maier C (2012) Microbial abundance in the coelenteron and mucus of the cold-water coral Lophelia pertusa and in bottom water of the reef environment. Aquat Biol 16:209-216

> Wild C, Woyt H, Huettel M (2005) Influence of coral mucus on nutrient fluxes in carbonate sands. Mar Ecol Prog Ser $287: 87-98$

Wild C, Naumann M, Niggl W, Haas A (2010) Carbohydrate composition of mucus released by scleractinian warmand cold-water reef corals. Aquat Biol 10:41-45

Williamson KE, Wommack KE, Radosevich M (2003) Sampling natural viral communities from soil for cultureindependent analyses. Appl Environ Microbiol 69: 6628-6633

> Wilson WH, Dale AL, Davy JE, Davy SK (2005) An enemy within? Observations of virus-like particles in reef corals. Coral Reefs 24:145-148

Young KD (2006) The selective value of bacterial shape. Microbiol Mol Biol R 70:660-703

Submitted: March 5, 2015; Accepted: September 10, 2015 Proofs received from author(s): October 21, 2015 